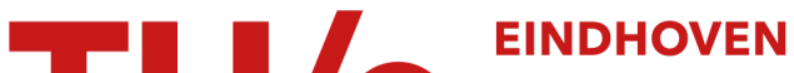 UNIVERSITY OF TECHNOLOGY
}

\section{Catalytic membrane reactor for the production of biofuels}

Citation for published version (APA):

Liuzzi, D., Pérez-Alonso, F. J., Fierro, J. L. G., Rojas, S., van Wijk, F. L., Roghair, I., van Sint Annaland, M., Fernandez Gesalaga, E., Viviente, J. L., \& Pacheco Tanaka, D. A. (2016). Catalytic membrane reactor for the production of biofuels. Catalysis Today, 37-45. https://doi.org/10.1016/j.cattod.2015.11.014

\section{Document license:}

TAVERNE

DOI:

10.1016/j.cattod.2015.11.014

Document status and date:

Published: $15 / 06 / 2016$

\section{Document Version:}

Publisher's PDF, also known as Version of Record (includes final page, issue and volume numbers)

\section{Please check the document version of this publication:}

- A submitted manuscript is the version of the article upon submission and before peer-review. There can be important differences between the submitted version and the official published version of record. People interested in the research are advised to contact the author for the final version of the publication, or visit the $\mathrm{DOI}$ to the publisher's website.

- The final author version and the galley proof are versions of the publication after peer review.

- The final published version features the final layout of the paper including the volume, issue and page numbers.

Link to publication

\section{General rights}

Copyright and moral rights for the publications made accessible in the public portal are retained by the authors and/or other copyright owners and it is a condition of accessing publications that users recognise and abide by the legal requirements associated with these rights.

- Users may download and print one copy of any publication from the public portal for the purpose of private study or research.

- You may not further distribute the material or use it for any profit-making activity or commercial gain

- You may freely distribute the URL identifying the publication in the public portal.

If the publication is distributed under the terms of Article $25 \mathrm{fa}$ of the Dutch Copyright Act, indicated by the "Taverne" license above, please follow below link for the End User Agreement:

www.tue.nl/taverne

\section{Take down policy}

If you believe that this document breaches copyright please contact us at:

openaccess@tue.nl

providing details and we will investigate your claim. 


\title{
Catalytic membrane reactor for the production of biofuels
}

\author{
Dalia Liuzzi ${ }^{a}$, Francisco José Pérez-Alonso ${ }^{a}, *$, José Luis G. Fierro ${ }^{a}$, Sergio Rojas $^{\mathrm{a}, * *}$, \\ Frank L. van Wijk ${ }^{\mathrm{b}}$, Ivo Roghair ${ }^{\mathrm{b}}$, Martin van Sint Annaland ${ }^{\mathrm{b}}$, Ekain Fernandez ${ }^{\mathrm{b}, \mathrm{c}}$, \\ Jose Luis Viviente ${ }^{c}$, D.A. Pacheco Tanaka ${ }^{c}$ \\ a Grupo de química y energías sostenibles, Instituto de Catálisis y Petroleoquímica, CSIC, Marie Curie, 2, Madrid, 28049 Spain \\ ${ }^{\mathrm{b}}$ Eindhoven University of Technology, Department of Chemical Engineering and Chemistry, Chemical Process Intensification group, P.O. Box 513, \\ Eindhoven, $5600 \mathrm{MB}$ The Netherlands \\ c TECNALIA, Energy and Environment Division, Mikeletegi Pasealekua 2, San Sebastian-Donostia, 20009 Spain
}

\section{A R T I C L E I N F O}

\section{Article history:}

Received 4 September 2015

Received in revised form 3 November 2015

Accepted 4 November 2015

Available online 12 December 2015

\section{Keywords:}

Biofuels

Membrane Reactors

Fischer Tropsch

Hydrogen

Ruthenium

1D model

\begin{abstract}
A B S T R A C T
The $\mathrm{H}_{2}$-distributed feeding concept using Pd/Ag-based membranes and an Ru-based catalyst in a Packed Bed Membrane Reactor ( $\mathrm{H}_{2}$-PBMR) for the synthesis of biofuels via the so-called Fischer-Tropsch Synthesis has been demonstrated. The most successful approach resulted when $\mathrm{H}_{2}$-poor syngas $\left(\mathrm{H}_{2} / \mathrm{CO}=1\right)$ typically obtained from the gasification of biomass was fed directly through the reaction chamber, i.e., to the catalyst bed, whereas the $\mathrm{H}_{2}$ needed to reach the proper stoichiometry for the FTS $\left(\mathrm{H}_{2} / \mathrm{CO}=2\right)$ was admitted, and properly distributed, into the catalyst bed through the Pd/Ag-based membrane by flowing $\mathrm{H}_{2} / \mathrm{He}$ mixtures at the retentate side of the membrane. Under the optimum reaction conditions, the CO conversion measured with the $\mathrm{H}_{2}$-distributed feeding concept is lower than that obtained in a conventional Packed Bed Reactor with $\mathrm{H}_{2} / \mathrm{CO}=2$ (37.9 vs 50.7\%), but significantly higher than that obtained in a conventional reactor with $\mathrm{H}_{2} / \mathrm{CO}=1(14.1 \%)$. Remarkably, the productivity towards high-molecular hydrocarbons increases by almost $70 \%$ and the methane production decreases by one order of magnitude when using the $\mathrm{H}_{2}$-distributed feeding concept in a Packed Bed Membrane Reactor.
\end{abstract}

(c) 2015 Elsevier B.V. All rights reserved.

\section{Introduction}

The Fischer-Tropsch Synthesis (FTS) is a well-established technology for the production of synthetic fuels and chemicals from syngas obtained from natural gas or coal [1]. The overall process comprises the transformation of natural gas or coal into syngas, a mixture of $\mathrm{H}_{2}$ and $\mathrm{CO}$ with different stoichiometries, depending on the source and reaction conditions, which is further transformed into hydrocarbons in the presence of a catalyst via the FTS. These processes are known as coal to liquids (CTL) or gas to liquid (GTL processes). In recent times, the possibility of obtaining syngas via biomass gasification has encouraged the interest in the FTS as a route for obtaining second-generation biofuels via the so-called BTL (biomass to liquid) process [2,3]. Industrial FTS plants are based on Fe- or Co-based catalysts producing mainly short olefins and gasoline or paraffinic waxes, respectively [4]. The scale of the CTL and

\footnotetext{
* Corresponding author. Tel.: +34 915854632 .

** Corresponding author. Tel. +3491585 4632.

E-mail addresses: fperez@icp.csic.es (F.J. Pérez-Alonso), srojas@icp.csic.es (S. Rojas).
}

GTL plants is a key factor in the economy of the overall processes. In fact, in order to be competitive, modern GTL plants are very large. For instance, it is reported that Shell's Pearl GTL plant in Qatar has the capacity of producing up to 260,000 barrels of GTL products and natural gas liquids per day treating 1.6 billion cubic feet per day of gas. However, it is highly unlikely that biomass could supply syngas at similar high rates as natural gas. As a consequence, it is expected that the scale of BTL plants have to be significantly smaller than that of CTL or GTL plants. Thus, in order to be competitive, it is necessary to increase the per-pass production of HC from syngas by developing more efficient processes and improving the catalysts to produce the desired hydrocarbon fraction. It is well known that Rubased catalysts exhibit remarkably higher intrinsic activities than Fe or Co catalysts [4]. Moreover, they can operate in the presence of high partial pressures of water (the main co-product of the FTS reaction) and other oxygenate-containing atmospheres that have triggered the interest in Ru-based catalysts for FTS [5-9].

The FTS results in the formation of a pool of heteroatom-free linear paraffinic hydrocarbons ranging from $\mathrm{CH}_{4}$ to waxes of 50 plus carbon atoms. The high molecular weight hydrocarbons are reformed downstream into the desired product family, mostly diesel or jet fuel fractions. Hydrocarbon formation in the FT reaction 
is very similar to polymerization kinetics in which hydrocarbons are formed by the addition of monomers of activated $C_{1}$ groups to the end of an absorbed growing hydrocarbon chain [10]. Due to this polymerization kinetics, there will always be a range of hydrocarbon products $C_{1}$, whose selectivity can be described by the Anderson, Schulz, Flory (ASF) distribution. The chain growth possibility, the $\alpha$ value (which ranges between 0 and 1 ) is commonly used to describe the product distribution of the FTS. The higher the $\alpha$ value, the higher the fraction of high molecular weight products.

The FTS product distribution can be controlled, at least to some extent, by the adequate use of the catalyst and reaction conditions (pressure, temperature, $\mathrm{H}_{2} / \mathrm{CO}$ ratio and Gas Hourly Space Velocity, GHSV) [10]. The use of membrane reactors offers the possibility of increasing process intensification, while increasing the reaction conversion and the selectivity towards the desired product fraction. However, studies about catalytic membrane reactors for the FTS are scarce, especially experimental studies. Most of these studies are based on $\mathrm{H}_{2} \mathrm{O}$-separation membranes in order to shift the equilibrium $\left(\mathrm{H}_{2}+\mathrm{CO} \rightarrow-\mathrm{CH}_{2}-+\mathrm{H}_{2} \mathrm{O}\right)$ to the formation of hydrocarbons. However, the results obtained show no benefits as compared to those reported in a Packed Bed Reactor (PBR), mostly because the membranes did not show sufficient selectivity for water removal under FTS conditions [11].

Membranes as reactant distributor along the reactor axis have been proposed to control the activity and product selectivity, since they depend significantly on the $\mathrm{H}_{2} / \mathrm{CO}$ ratio. Thus, the concept of distributed feeding of $\mathrm{H}_{2}$ can be used to enhance the selectivity to long-chain products, since the $\mathrm{H}_{2} / \mathrm{CO}$ ratio remains constant along the reactor axis [12]. Leonard et al. [13,14] and Guillou et al. [15] presented a conceptual study on distributed feeding of $\mathrm{H}_{2}$ along the reactor axis. The membrane was either inert $\left(\gamma-\mathrm{Al}_{2} \mathrm{O}_{3}\right.$ on $\left.\alpha-\mathrm{Al}_{2} \mathrm{O}_{3}\right)$ or coated with a ZSM-5 zeolite layer. The distribution of $\mathrm{H}_{2}$ into a $\mathrm{CO}$ feed stream lead to low $\mathrm{H}_{2} / \mathrm{CO}$-ratios in the catalytic bed and as a consequence to lower conversions along with higher $\mathrm{C}_{10+}$ hydrocarbon yield and lower methane selectivity. In addition, low $\mathrm{H}_{2} / \mathrm{CO}$ ratios could result in a higher formation of coke and/or high molecular weight hydrocarbons that remain adsorbed on the catalyst surface thus deactivating the catalyst. The application of the ZSM-5 membrane also altered the product distribution by secondary reactions at the acidic sites of the zeolite, resulting in higher yields of short-chain hydrocarbons. These results show a promising alternative to convert biomass-derived $\mathrm{H}_{2}$-poor syngas into valuable hydrocarbons.

Recently, some works have modeled the use of membrane reactors for the FTS. Rahimpour et al. proposed a 1D heterogeneous model of the FTS reactor using Fe-based catalysts in which a fixed bed reactor is combined with a membrane-assisted fluidized bed reactor. The results obtained by the model showed an enhancement in the gasoline yield, a main decrease in $\mathrm{CO}_{2}$ formation and a favorable temperature profile compared with a conventional fixed bed reactor [16].

More recently, Ghareghashi et al. [17] reported a simulation of the use of two consecutive reactors: a catalytic fixed bed reactor for the oxidative coupling of methane (OCM) and a fixed bed membrane FTS reactor using a $\mathrm{Pd} / \mathrm{Ag}$ based $\mathrm{H}_{2}$ perm-selective membrane and an Fe-based catalyst. The study concluded that the concept of a membrane FTS reactor together with OCM feed is an interesting method for increasing $\mathrm{C}_{5+}$ and decreasing undesired products such as $\mathrm{CO}_{2}$ and methane.

In addition, Nouryzadeh et al. modeled the $\mathrm{H}_{2}$ and gasoline production in a heat exchanger reactor [18] called Thermally Coupled Recuperative Reactor which is composed of two concentric tubular fixed bed reactors. In this interesting concept, the exothermic reaction (FTS) generates heat that is transferred to the endothermic side (outer side) where the dehydrogenation of cyclohexane to produce $\mathrm{H}_{2}$ takes place. The $\mathrm{H}_{2}$ produced is fed along the FTS reactor through a Pd/Ag perm-selective membrane. According to the model results, this configuration offered some important improvements compared with the conventional FTS, thus increasing the gasoline yield.

In summary, some experimental results and especially some recent modeling studies indicate that the use of the so-called $\mathrm{H}_{2}$ distributed feeding concept in FTS by using membrane reactors could have a beneficial effect enhancing the selectivity towards high molecular weight hydrocarbons while decreasing the selectivity to undesired methane and/or $\mathrm{CO}_{2}$. Moreover, the use of $\mathrm{Pd} / \mathrm{Ag}$ membranes have recently received great interest due to their unique properties for the separation of $\mathrm{H}_{2}$, high permeability and selectivity to $\mathrm{H}_{2}[19,20]$. These improved properties could help to implement the use of $\mathrm{H}_{2}$-distributed feeding concept in a membrane reactor applied to the FTS.

To the best of our knowledge, there are no experimental works about the use of the $\mathrm{H}_{2}$-distributed feeding concept with membrane reactors for FTS using Pd/Ag membranes.

In this paper, we show the beneficial effect of using $\mathrm{Pd} / \mathrm{Ag}$ membranes for $\mathrm{H}_{2}$-distributed feeding in a Packed Bed Membrane Reactor (PBMR) compared to a conventional Packed Bed Reactor (PBR) for FTS with a Ru-based catalyst. $\mathrm{H}_{2}$-poor syngas $\left(\mathrm{H}_{2} / \mathrm{CO}=1\right)$, which is the typical value of the syngas obtained by gasification of biomass [21], was fed to the reaction chamber (inner side of the membrane) and the $\mathrm{H}_{2}$ needed to reach the desired FTS stoichiometry $\left(\mathrm{H}_{2} / \mathrm{CO}=2\right)$ was admitted (and properly distributed) into the reaction chamber through the $\mathrm{Pd} / \mathrm{Ag}$-based membrane resulting in an enhancement of the productivity of high molecular weight hydrocarbons. The experimental study is supported by model simulations.

\section{Experimental}

\subsection{Preparation of the $\mathrm{B}-\mathrm{Ru} / \mathrm{TiO}_{2}$ catalyst}

B-doped $\mathrm{Ru} / \mathrm{TiO}_{2}$ (3 wt\% Ru; B:Ru 1:1 at), RuB1Ti was used as the FTS catalyst. The catalyst was prepared by sequential impregnation of $\mathrm{TiO}_{2}(\mathrm{P} 25)$ with water solutions of $\mathrm{RuNO}\left(\mathrm{NO}_{3}\right)_{3}$ and $\mathrm{HBO}_{3}$. A solution of the Ru precursor was added to $\mathrm{TiO}_{2}$ by incipient wetness impregnation with a $0.09-\mathrm{M}$ aqueous solution of Ru precursor and dried overnight. The solid recovered was calcined in static air at $450{ }^{\circ} \mathrm{C}\left(10^{\circ} \mathrm{C} \mathrm{min}^{-1}\right)$ for $3 \mathrm{~h}$. The resulting solid $\left(\mathrm{Ru} / \mathrm{TiO}_{2}\right)$ was impregnated with aqueous solution with the adequate amount of $\mathrm{H}_{3} \mathrm{BO}_{3}$ to obtain a $\mathrm{B} / \mathrm{Ru}$ atomic ratio of 1 , dried at room temperature and calcined again in static air at $450^{\circ} \mathrm{C}\left(10^{\circ} \mathrm{C} \mathrm{min}^{-1}\right)$ for $3 \mathrm{~h}$.

\subsection{Catalyst characterization}

X-ray diffractograms were collected on a Seifert 3000 powder diffractometer operating with $\mathrm{Cu} K \alpha$ radiation $(\lambda=0.15418 \mathrm{~nm})$ generated at $40 \mathrm{kV}$ and $40 \mathrm{~mA}$. Scans were recorded at $0.02{ }^{\circ} \mathrm{s}^{-1}$ for $2 \theta$ values between $10^{\circ}$ and $90^{\circ} . \mathrm{H}_{2}$ temperature-programmed reduction $\left(\mathrm{H}_{2}-\mathrm{TPR}\right)$ analysis of the catalyst was carried out with a Micromeritics instrument using a U-shaped quartz reactor. Prior to the reduction experiment, the catalyst was flushed with a $\mathrm{He}$ stream at $373 \mathrm{~K}$ for $30 \mathrm{~min}$ and then cooled down to room temperature. TPR profiles were obtained by heating the sample under a $10 \% \mathrm{H}_{2} /$ Ar flow $\left(50 \mathrm{~mL} \mathrm{~min}^{-1}\right.$ ) from 303 to $1173 \mathrm{~K}\left(10 \mathrm{~K} \mathrm{~min}^{-1}\right)$.

\subsection{Preparation of Pd/Ag-supported membranes}

A 15-cm long alumina tube with an outside pore size of $100 \mathrm{~nm}$ and $10 / 7 \mathrm{~mm}$ o.d/i.d. was used as membrane support (provided by Rauschert Kloster Veilsdorf), both ends were glazed leaving $60 \mathrm{~mm}$ of porous part in the middle of the membrane. A thin Pd-Ag layer ( $\approx 4 \mu \mathrm{m}$ thick and silver content of $\sim 23-27 \%$ ) was deposited on the 

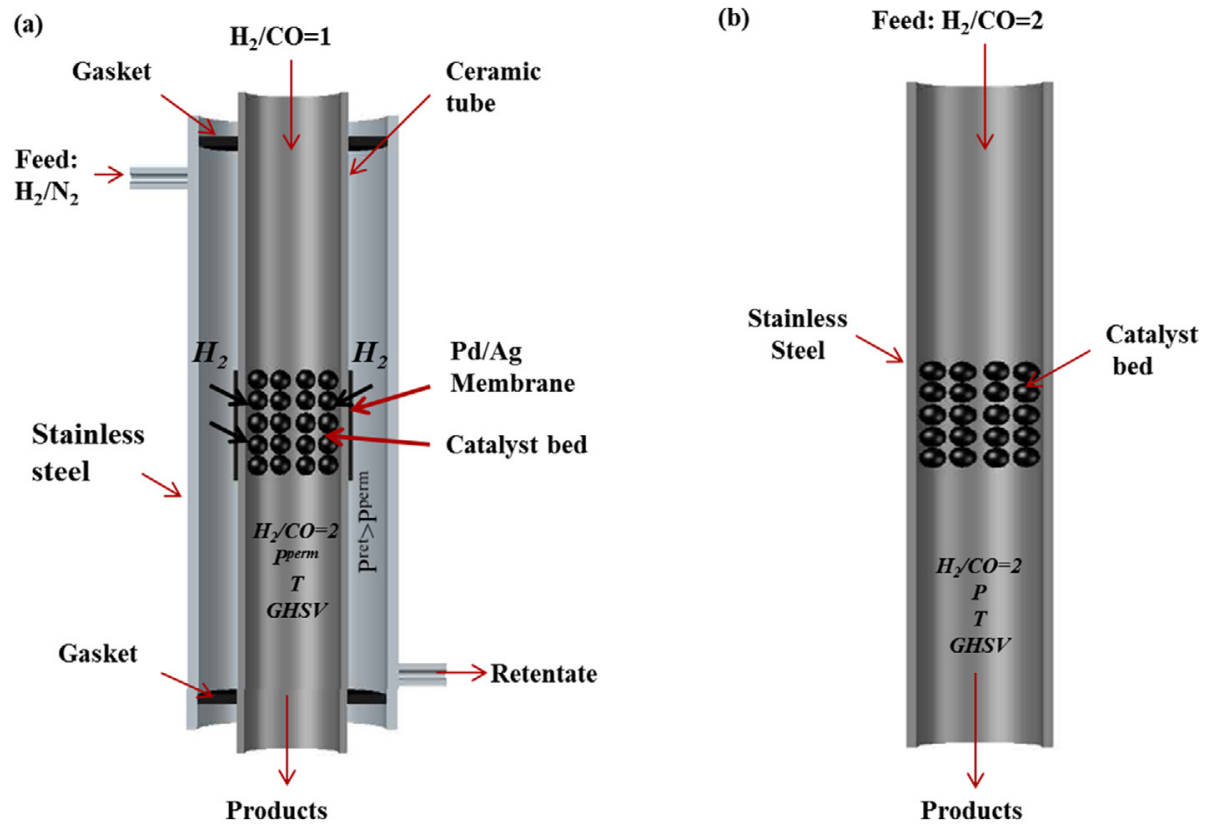

Fig. 1. (a) Scheme of the membrane reactor for $\mathrm{H}_{2}$ distributed feeding $\left(\mathrm{H}_{2}\right.$-PBMR); (b) scheme of traditional PBR.

porous alumina tube first by simultaneous $\mathrm{Pd}$ and $\mathrm{Ag}$ electroless plating (containing $13-15 \%$ of $\mathrm{Ag}$ ) [20] in order to increase the amount of $\mathrm{Ag}$ to avoid fragilization, more $\mathrm{Ag}$ was deposited by PVD magnetron sputtering (CemeCon CC800/8) using an Ag target with similar conditions of deposition as reported before [22]. After the deposition of the $\mathrm{Ag}$ layer, the membrane layer was annealed at $823 \mathrm{~K}$ for $4 \mathrm{~h}$ under a $10 \% \mathrm{H}_{2} / 90 \% \mathrm{~N}_{2}$ gas mixture. Similar Pd-Ag membranes $(\approx 3.2-\mu \mathrm{m}$ thick and silver content of 13-15\%) showed a $\mathrm{H}_{2}$ permeance of $0.0025 \mathrm{~mol} \mathrm{~m}^{-2} \mathrm{~s}^{-1} \mathrm{~Pa}^{-0.5}$ at $587 \mathrm{~K}$ when feeding pure $\mathrm{H}_{2}$ [20].

\subsection{Catalytic activity tests}

Catalytic tests in a Packed Bed Reactor (PBR) and in a Packed Bed Membrane Reactor (PBMR) were conducted at temperatures of 523 and $553 \mathrm{~K}, P=1.0 \mathrm{MPa}$ and $\mathrm{GHSV}=7500 \mathrm{~mL}_{\text {syngas }} / \mathrm{g}_{\text {cat }} / \mathrm{h}$. In the PBMR configuration, the catalyst was placed inside of the alumina membrane assuring that its location coincides with that of the Pd-Ag layer. With this configuration, it would be expected that $\mathrm{H}_{2}$ permeated from the outer layer of the membrane would only be distributed along the catalytic area in the reactor. Prior to the catalytic tests, the catalyst was activated in situ by flowing $\mathrm{H}_{2}$ at $523 \mathrm{~K}$ for $60 \mathrm{~min}$ to ensure the formation of the active phase for the FTS. In the PBR, syngas $\left(\mathrm{H}_{2} / \mathrm{CO}=2\right)$ is fed to the catalytic chamber. However, in the PBMR, $\mathrm{CO}$ and $\mathrm{H}_{2}$ are fed to the catalytic bed through the catalytic chamber $(\mathrm{CO})$ and through the membrane side $\left(\mathrm{H}_{2}\right)$ so that the overall ratio $\mathrm{H}_{2} / \mathrm{CO}=2$ is achieved. For this purpose, the $\mathrm{H}_{2}$ permeation through the membrane was measured by flowing $\mathrm{H}_{2}$ and $\mathrm{CO}$ through the retentate and the permeate sides of the membrane, respectively (see Fig. 1).

The analysis of the reaction products was done with an in-line GC equipped with FID and TCD detectors equipped with a cryogenic unit.

\section{Modeling}

\subsection{Model description}

A state-of-the-art pseudo-homogeneous $1 \mathrm{D}$ reactor model is employed for simulations of the multi-compartment packed bed and packed bed membrane reactor. The model solves the mass and energy balances of all the compartments simultaneously. In the mass balances accumulation (left-hand side), convection, axial dispersion and heterogeneously catalyzed chemical reactions and a membrane source/sink term, respectively, on the right-hand side has been accounted for:

$\frac{\partial \varepsilon_{\mathrm{g}} \rho_{\mathrm{g}} \omega_{i}}{\partial t}=-\frac{\partial \varepsilon_{\mathrm{g}} \rho_{\mathrm{g}} u_{\mathrm{g}} \omega_{i}}{\partial z}+\frac{\partial}{\partial z}\left(\rho_{\mathrm{g}} D_{\mathrm{ax}} \frac{\partial \omega_{i}}{\partial z}\right)+n_{i} a_{\mathrm{s}}+\varphi_{\mathrm{m}, i}^{\prime \prime} a_{\mathrm{m}}$

The equations are solved using Danckwerts inlet boundary conditions and free-flow outlet conditions:

$-\left.D_{\mathrm{ax}} \rho_{\mathrm{g}} \frac{\partial \omega_{i}}{\partial z}\right|_{z=0}+\left.\varepsilon_{\mathrm{g}} \rho_{\mathrm{g}} u_{\mathrm{g}} \omega_{i}\right|_{z=0}=\left.\varphi_{\text {inlet }, i}^{\prime \prime} \quad \frac{\partial \omega_{i}}{\partial z}\right|_{z=L}=0$

The energy balance is formulated in a similar fashion, with an additional term for heat exchange via the confining wall.

$$
\begin{aligned}
\varepsilon_{\mathrm{g}} \rho_{\mathrm{g}} C_{\mathrm{p}, \mathrm{g}} \frac{\partial T}{\partial t}= & -\varepsilon_{\mathrm{g}} \rho_{\mathrm{g}} C_{\mathrm{p}, \mathrm{g}} u_{\mathrm{g}} \frac{\partial T}{\partial z}+\frac{\partial}{\partial z}\left(\lambda_{\mathrm{g}, \mathrm{eff}} \frac{\partial T}{\partial z}\right)+\sum_{i=1}^{N} n_{i} a_{\mathrm{s}} H_{i} \\
& +\sum_{i=1}^{N} \varphi_{\mathrm{m} . i}^{\prime \prime} a_{\mathrm{m}} H_{i}+a_{\mathrm{b} \rightarrow \mathrm{w}} a_{\mathrm{w}}\left(T-T_{\infty}\right)
\end{aligned}
$$

with similar Danckwerts inlet and free-flow outlet conditions:

$-\left.\lambda_{\mathrm{g}} \frac{\partial T}{\partial z}\right|_{z=0}+\left.\varepsilon_{\mathrm{g}} \rho_{\mathrm{g}} C_{\mathrm{p}, \mathrm{g}} u_{\mathrm{g}} T\right|_{z=0}=\left.\sum_{i=1}^{N} H_{i} \varphi_{\text {inlet }, i}^{\prime \prime} \quad \frac{\partial T}{\partial z}\right|_{z=L}=0$

Mass conservation was enforced via the total continuity equation:

$\varepsilon_{\mathrm{g}} \frac{\partial \rho_{\mathrm{g}}}{\partial t}=-\frac{\partial \rho_{\mathrm{g}} u_{\mathrm{g}}}{\partial z}-\phi_{\mathrm{m}, \text { tot }}^{\prime \prime} a_{\mathrm{m}}$ with $a_{\mathrm{m}}=\frac{4 d_{\mathrm{i}}}{d_{\mathrm{o}}^{2}-d_{\mathrm{i}}^{2}}$

where, $d_{\mathrm{o}}$ and $d_{\mathrm{i}}$ represent the outer and inner diameter, respectively, while the pressure drop over the catalyst bed was computed using the differential Ergun equation.

The multi-compartment layout is used to describe the different parts of the Packed Bed Membrane Reactor (PBMR), i.e., the reactor tube (compartment 1 ) and the membrane tube (compartment 
Table 1

Experimentally determined membrane parameters for the used Pd/Ag membrane, which were set in the numerical model.

\begin{tabular}{lll}
\hline Parameter & Value & Unit \\
\hline$Q_{\text {Pd }, 0}$ & $6.135 \times 10^{-8}$ & $\mathrm{~mol} \mathrm{~m}^{-1} \mathrm{~s}^{-1} \mathrm{~Pa}^{-\mathrm{n}}$ \\
$E_{\text {act,pd }}$ & 7.799 & $\mathrm{~kJ} \mathrm{~mol}^{-1}$ \\
$\delta$ & $4.8 \times 10^{-6}$ & $\mathrm{M}$ \\
$n$ & 0.5 & \\
\hline
\end{tabular}

2). Exchange of hydrogen between the two compartments via the $\mathrm{Pd}-\mathrm{Ag}$ perm-selective membrane is described with Sieverts' law:

$J_{\mathrm{H}_{2}}=\frac{Q_{\mathrm{Pd}}}{\delta}\left(p_{\mathrm{H}_{2}, \text { tube }}^{n}-p_{\mathrm{H}_{2}, \text { shell }}^{n}\right)$ with $Q_{\mathrm{Pd}}=Q_{\mathrm{Pd}, 0} \exp \left(-\frac{E_{\mathrm{act}, \mathrm{Pd}}}{R T}\right)$

where, the parameters were fitted to permeance data obtained from dedicated experiments (see Table 1 ).

The FTS reaction kinetics have been based on the reaction scheme proposed by Visconti et al. [23-25] for Co-based catalysts (listed in Table 2), but with modified kinetic parameters for the Ru-based catalyst used in this work.

The reaction rate constant in reaction 1 and $2 \mathrm{a}$ is modeled using a modified Arrhenius equation:

$k=k_{0} \exp \left[-\frac{E_{\mathrm{a}}}{R}\left(\frac{1}{T}-\frac{1}{503}\right)\right]$

The implementation of the kinetic scheme was verified by comparing simulations to results published in the works by Visconti and coworkers, which gave satisfactory results. The $\mathrm{Ru}-\mathrm{B} / \mathrm{TiO}_{2}$-based catalyst was modeled by changing the kinetic rate parameters and activation energies, so that simulation results would closely match the experimental kinetic results. This fitting procedure was performed by manually fitting the most important kinetic rate parameters to match experimental and simulated conversion and selectivities using a base case of $P=20 \mathrm{bar}, T=523 \mathrm{~K}$, $\mathrm{GHSV}=10,000 \mathrm{~mL} / \mathrm{g}_{\text {cat }} / \mathrm{h}$ and $\mathrm{a} \mathrm{H}_{2} / \mathrm{CO}$ ratio of 2 . Comparison with experiments at different temperatures indicated a required change in the activation energies of kinetic rate equations 1 and $2 a$ (Table 2). Table 3 gives the newly fitted parameters for the Ru$\mathrm{B} / \mathrm{TiO}_{2}$-based catalyst, along with those provided by Visconti [23] for their Co-based catalyst. Table 4 shows the results of a comparison of the quality of the fit between the $\mathrm{Ru}-\mathrm{B} / \mathrm{TiO}_{2}$ experiments and simulations.
Table 3

Values of the fitted kinetic parameters for the $\mathrm{Ru}-\mathrm{B} / \mathrm{TiO}_{2}$ catalyst and the original Co-based values from reference [23].

\begin{tabular}{|c|c|c|c|}
\hline \multirow[b]{2}{*}{ Parameter } & \multicolumn{3}{|l|}{ Value } \\
\hline & Fit $\mathrm{Ru}-\mathrm{B} / \mathrm{TiO}_{2}$ & Co-based & Unit \\
\hline$k_{\mathrm{H} 2,0}$ & $1.14 \times 10^{-04}$ & $3.77 \times 10^{-05}$ & $\mathrm{mmol} \mathrm{s}^{-1} \mathrm{~g}^{-1}$ bar $^{-1}$ \\
\hline$E_{\mathrm{a}, \mathrm{H} 2}$ & 71.51 & 267.3 & $\mathrm{~kJ} \mathrm{~mol}^{-1}$ \\
\hline$k_{\mathrm{M}, 0}$ & $4.11 \times 10^{-03}$ & $1.36 \times 10^{-03}$ & $\mathrm{mmol} \mathrm{s}^{-1} \mathrm{~g}^{-1} \mathrm{bar}^{-1}$ \\
\hline$E_{\mathrm{a}, \mathrm{M}}$ & 37.986 & 177.44 & $\mathrm{~kJ} \mathrm{~mol}^{-1}$ \\
\hline$k_{\mathrm{IN}}$ & 1.01 & 0.334 & $\mathrm{mmols}^{-1} \mathrm{~g}^{-1}$ \\
\hline$k_{\mathrm{CH} 4}$ & 9.74 & 1.61 & $\mathrm{mmol} \mathrm{s}^{-1} \mathrm{~g}^{-1}$ \\
\hline$k_{\mathrm{G}}$ & 0.513 & 0.226 & $\mathrm{mmol} \mathrm{s}^{-1} \mathrm{~g}^{-1}$ \\
\hline$k_{\mathrm{Pn}}$ & 0.948 & 0.132 & $\mathrm{mmol} \mathrm{s}^{-1} \mathrm{~g}^{-1}$ \\
\hline$k_{\mathrm{Qn}, \mathrm{dx}}$ & 0.182 & $5.54 \times 10^{-03}$ & $\mathrm{mmol} \mathrm{s}^{-1} \mathrm{~g}^{-1}$ \\
\hline$k_{\mathrm{Qn}, \mathrm{sx}}$ & 8.24 & 3.63 & $\mathrm{mmol} \mathrm{s}^{-1} \mathrm{~g}^{-1} \mathrm{bar}^{-1}$ \\
\hline$k_{\mathrm{Q} 2, \mathrm{sx}}$ & 402 & 164 & $\mathrm{mmols}^{-1} \mathrm{~g}^{-1}$ bar $^{-1}$ \\
\hline
\end{tabular}

Table 4

Comparison of model and experimental results using the fitted kinetic parameters. The selectivity $(S)$, olefin over paraffin ratio $(Q / P)$ and CO conversion $(X)$ were used as indicators for the quality of the fitting.

\begin{tabular}{llll}
\hline Indicator & Experimental results & Model results & RMS deviation \\
\hline$S\left(C_{1}\right)$ & 0.16 & 0.1469 & 0.0131 \\
$S\left(C_{2}-C_{5}\right)$ & 0.21 & 0.2375 & 0.0275 \\
$S\left(C_{5+}\right)$ & 0.64 & 0.6156 & 0.0244 \\
$Q / P\left(C_{2}-C_{5}\right)$ & 0.9 & 0.9374 & 0.0374 \\
$Q / P\left(C_{6}-C_{10}\right)$ & 0.6 & 0.6621 & 0.0621 \\
$X$ & 0.37 & 0.3486 & 0.0214 \\
\hline
\end{tabular}

\section{Results}

\subsection{Catalyst characterization}

Fig. 2a shows the $\mathrm{X}$-ray diffractograms of the $\mathrm{B}-\mathrm{Ru} / \mathrm{TiO}_{2}$ catalyst. The diffractogram of the $\mathrm{TiO}_{2}$ is shown for comparison. As observed, both diffractograms show identical diffraction lines characteristic for the rutile and anatase phases of $\mathrm{TiO}_{2}$. Diffraction lines indicative of $\mathrm{Ru}$ or $\mathrm{B}$ phases are not observed, indicating that $\mathrm{Ru}$ is well dispersed onto the $\mathrm{TiO}_{2}$ support. Fig. 2b shows the $\mathrm{H}_{2}$ consumption profile $v s$ temperature for $\mathrm{B}-\mathrm{Ru} / \mathrm{TiO}_{2}$. A single peak centered at $c a$. $450 \mathrm{~K}$ is observed indicating a good dispersion of the Ru particles onto $\mathrm{TiO}_{2}$.

\subsection{Pd/Ag membranes: effect of $\mathrm{CO}$ on $\mathrm{H}_{2}$ flux permeated}

Prior to the FTS tests in the PBMR configuration, the $\mathrm{H}_{2}$ flux through the membrane and the effect of the presence of $\mathrm{CO}$ on the $\mathrm{H}_{2}$ permeation through the $\mathrm{Pd} / \mathrm{Ag}$ membranes was studied. To conduct these experiments, the volume of inert material ( $\mathrm{SiC}$ ) sufficient

Table 2

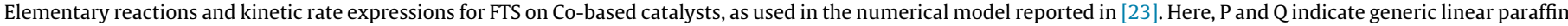
and olefins, respectively, and $\theta$ indicates the fraction of free catalytic sites, while ${ }^{*}$ indicates a single free catalytic site.

\begin{tabular}{|c|c|c|c|}
\hline Step & Elementary reaction & Equilibrium/kinetic expression & Notes \\
\hline 1. & $\mathrm{H}_{2}+2^{*} \Leftrightarrow 2 \mathrm{H}^{*}$ & $r \mathrm{H}_{2}=k \mathrm{H}_{2} P_{\mathrm{H}_{2}} \theta^{2} \theta_{\mathrm{H}^{*}}^{-1}$ & \\
\hline 2a. & $\mathrm{CO}+{ }^{*} \Leftrightarrow \mathrm{CO}^{*}$ & $r_{\mathrm{M}}=k_{\mathrm{M}} P_{\mathrm{CO}} \theta$ & $\begin{array}{l}\text { Reaction } 2 \mathrm{a} \text { is rate-limiting, } \\
\text { followed by reactions } 2 \mathrm{~b}-2 \mathrm{f}\end{array}$ \\
\hline 2b. & $\mathrm{CO}^{*}+{ }^{*} \Leftrightarrow \mathrm{C}^{*}+\mathrm{O}^{*}$ & & \\
\hline $2 c$. & $\mathrm{C}^{*}+\mathrm{H}^{*} \rightarrow \mathrm{CH}^{*}+{ }^{*}$ & & \\
\hline $2 \mathrm{~d}$. & $\mathrm{CH}^{*}+\mathrm{H}^{*} \rightarrow \mathrm{CH}_{2}{ }^{*}+{ }^{*}$ & & \\
\hline 2e. & $\mathrm{O}^{*}+\mathrm{H}^{*} \rightarrow \mathrm{OH}^{*}+*$ & & \\
\hline $2 \mathrm{f}$. & $\mathrm{OH}^{*}+\mathrm{H}^{*} \rightarrow \mathrm{H}_{2} \mathrm{O}+2^{*}$ & & \\
\hline 3. & $\mathrm{CH}_{2}{ }^{*}+\mathrm{H}^{*} \rightarrow \mathrm{CH}_{3}{ }^{*}+{ }^{*}$ & $r_{\mathrm{IN}}=k_{\mathrm{IN}} \theta \mathrm{CH}_{2^{*}} \theta_{\mathrm{H} *}$ & \\
\hline 4. & $\mathrm{CH}_{3}{ }^{*}+\mathrm{H}^{*} \rightarrow \mathrm{CH}_{4}+2^{*}$ & $r_{\mathrm{CH}_{4}}=k_{\mathrm{CH}_{4}} \theta_{\mathrm{CH}_{3}^{*}} \theta_{\mathrm{H} *}$ & \\
\hline 5. & $\mathrm{R}_{n}{ }^{*}+\mathrm{CH}_{2}{ }^{*} \rightarrow \mathrm{R}_{n}+{ }_{1}^{*}+{ }^{*}$ & $r_{\mathrm{G}, n}=k_{\mathrm{G}} \theta_{\mathrm{R}_{n} *} \theta_{\mathrm{CH}_{2 *}}^{3}$ & $n: 1 \rightarrow 49$ \\
\hline 6. & $\mathrm{R}_{n}^{*}+\mathrm{H}^{*} \rightarrow \mathrm{P}_{n}+2^{*}$ & $r_{\mathrm{P}, n}=k_{\mathrm{P}_{n}} \theta_{\mathrm{R}_{n}^{*}} \theta_{\mathrm{H} *}$ & $n: 2 \rightarrow 50$ \\
\hline 7. & $\mathrm{R}_{n}^{*} \leftrightarrow \mathrm{Q}_{n}+\mathrm{H}^{*}$ & $-k_{\mathrm{Q}_{n} . \mathrm{sx}} x_{\mathrm{Q}_{n}}^{n} \theta_{\mathrm{H} *}$ & $n: 3 \rightarrow 50$ \\
\hline 8. & $\mathrm{R}_{2}{ }^{*} \leftrightarrow \mathrm{Q}_{2}+\mathrm{H}^{*}$ & $r_{Q_{2}}=k_{Q_{2}, \mathrm{dx}} \theta_{R_{2}^{*}}-k_{\mathrm{Q}_{2, \mathrm{sx}}} x_{\mathrm{Q}_{2}} \theta_{\mathrm{H} *}$ & \\
\hline
\end{tabular}



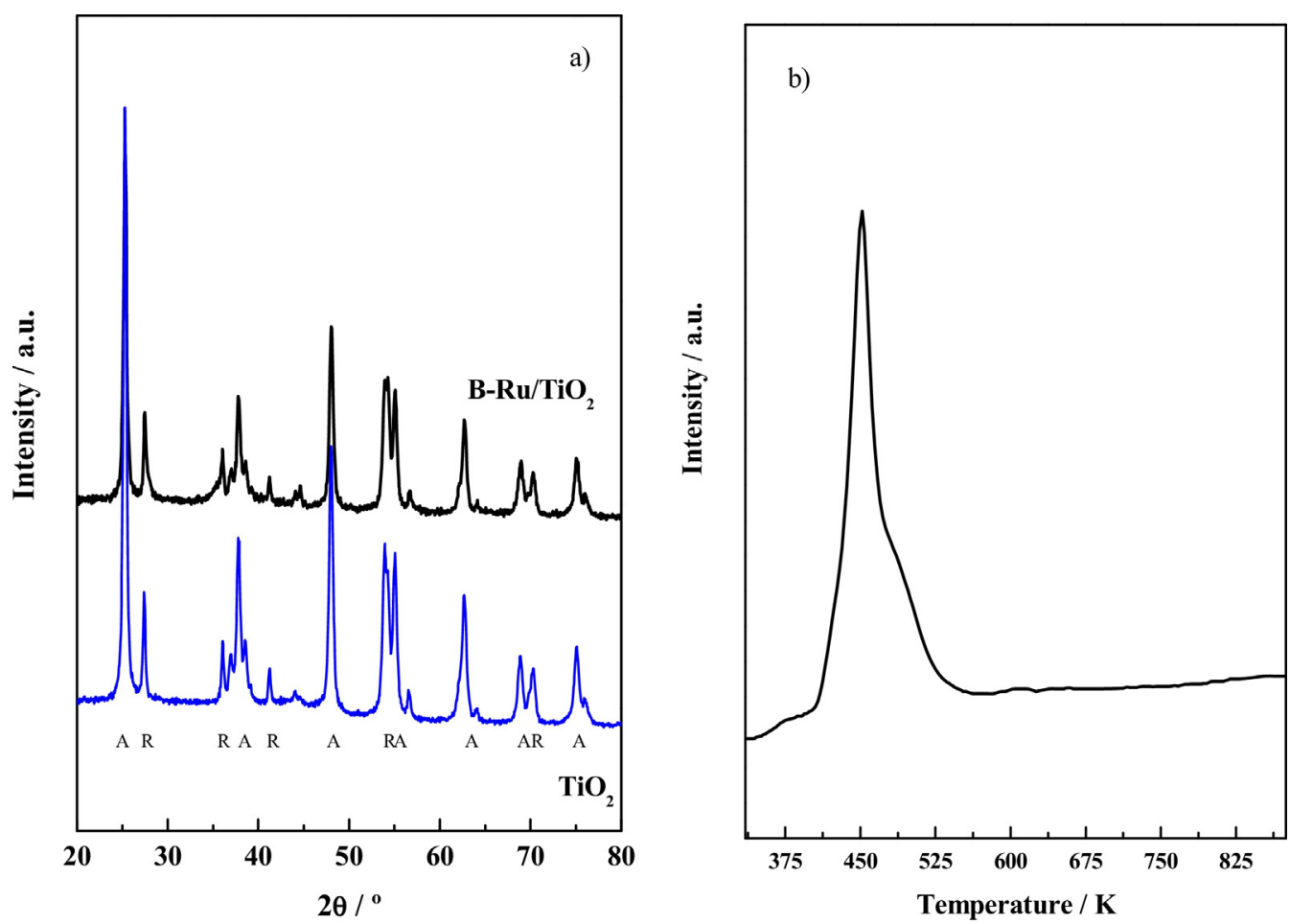

Fig. 2. (a) X-ray diffractograms for $\mathrm{B}-\mathrm{Ru} / \mathrm{TiO}_{2}$ and $\mathrm{TiO}_{2}$. The anatase (A) and rutile(R) phases of $\mathrm{TiO}_{2}$ are indicated. (b) $\mathrm{H}_{2}$-consumption profile of $\mathrm{B}-\mathrm{Ru} / \mathrm{TiO} \mathrm{C}_{2}$.

to fill the length of the membrane was placed inside the membrane and the temperature of reactor was raised to $553 \mathrm{~K}$ under He flow $\left(170 \mathrm{~mL} \mathrm{~min}^{-1}\right)$. Once this temperature was reached, the He total pressure at the outer side of the membrane was set between 0.1 and $0.3 \mathrm{MPa}$, while the inner side of the membrane was maintained at atmospheric pressure. The He flux permeated through the $\mathrm{Pd} / \mathrm{Ag}$ membrane (or sealing) was less than $2 \%$ of the total He flow within the entire pressure range under study. In a following step, the $\mathrm{H}_{2}$ permeation was measured at $553 \mathrm{~K}$ using $103 \mathrm{~mL} \mathrm{~min}^{-1}$ of $\mathrm{H}_{2}$ and a constant flow rate of $75.6 \mathrm{~mL} \mathrm{~min}^{-1}$ of $\mathrm{He}$ at $0.1 \mathrm{MPa}$ at the inner part of the membrane. In order to study the effect of $\mathrm{CO}$ on the $\mathrm{H}_{2}$ permeation rate, the experiments were also conducted by flowing $\mathrm{CO} / \mathrm{N}_{2}(80 / 20) 75.6 \mathrm{~mL} \mathrm{~min}^{-1}$ instead of He at the inner part of the membrane. The $\mathrm{H}_{2}$ pressure at the outer side of the membrane ranged between 0.1 and $0.3 \mathrm{MPa}$ in all cases. The results are shown in Fig. 3. The difference of $\mathrm{H}_{2}$ partial pressure was calculated by assuming that the $\mathrm{H}_{2}$ pressure inside the membrane was zero.

The results shown in Fig. 3 clearly indicate that the permeability of the Pd/Ag membrane decreases when $\mathrm{CO}$ is fed through the inner side of the membrane. This is caused by the stronger adsorption of $\mathrm{CO}$ compared to $\mathrm{H}_{2}$ onto the Pd atoms, thus decreasing the $\mathrm{H}_{2}$ permeation. However, this poisoning effect is not complete, and the presence of $\mathrm{CO}$ does not lead to complete deactivation of the membrane permeation at the temperatures and pressures used in this study, and still a quite high $\mathrm{H}_{2}$ permeation is observed even with a $\mathrm{CO} / \mathrm{N}_{2}$ flux at the inner side of the membrane. Thus, it can be concluded that it is possible to obtain sufficient $\mathrm{H}_{2}$ permeation under FTS conditions by using Pd/Ag membranes.

\subsection{FTS activity tests: PBMR vs PBR}

Pd membranes are typically designed to work at temperatures above $573 \mathrm{~K}$, whilst the reaction of Fischer-Tropsch with a Ru-based catalyst like the one used in this work is usually carried out at temperatures between $488 \mathrm{~K}$ and $523 \mathrm{~K}$. At these low temperatures, Pd membranes suffer from the so-called "embrittlement" effect, which is a metal degradation process due to the coexistence of the hybrids $\mathrm{H}_{2}-\mathrm{Pd}(\alpha-\beta)$ in the membrane [26]. Pd/Ag membranes are more resistant to embrittlement; however, due to the high pressure of $\mathrm{H}_{2}$ in the reaction and higher $\mathrm{H}_{2}$ permeation at higher temperatures, temperatures above $523 \mathrm{~K}$ were selected. As a consequence, it can be anticipated that a mismatch between the optimum reaction conditions for the FTS and the optimum working conditions of the membranes exists that could limit the implementation of PBMR for FTS. Therefore, operation conditions must be chosen as a compromise between the optimal ones for the FTS and for $\mathrm{H}_{2}$ permeation, or further optimization of the catalyst and/or membrane needs to be pursued.

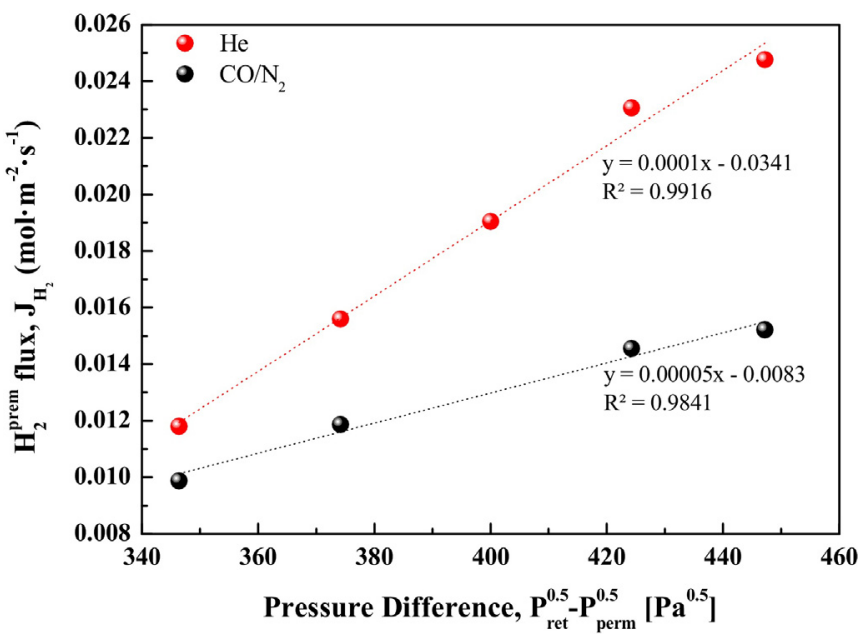

Fig. 3. $\mathrm{H}_{2}$ flux of Pd/Ag membrane at $553 \mathrm{~K}\left(\mathrm{H}_{2}\right.$ fed $\left.103.2 \mathrm{~mL}_{\mathrm{N}} / \mathrm{min}\right)$ vs pressure difference feeding $\mathrm{He}$ (red) and $\mathrm{CO} / \mathrm{N}_{2}$ (black) inside the membrane. (For interpretation of the references to color in this figure legend, the reader is referred to the web version of this article). 
In a first approach, the $\mathrm{H}_{2}$-PBMR FTS tests were conducted at $523 \mathrm{~K}$ with a feed composition of $\mathrm{H}_{2} / \mathrm{CO} / \mathrm{N}_{2}=46 / 46 / 8$ to the inner compartment. Note that the $\mathrm{H}_{2} / \mathrm{CO}$ ratio is equal to 1 , similar to the one obtained from biomass gasification, but lower than the stoichiometric $\mathrm{H}_{2} / \mathrm{CO}$ ratio for the FTS. To compensate the lack of $\mathrm{H}_{2}$ (with respect to the stoichiometric FTS value), $\mathrm{H}_{2}$ is permeated homogenously through the outer side of the membrane (along the whole length of the membrane) by flowing a mixture of $\mathrm{H}_{2} / \mathrm{He}$ to the outer side of the membrane. In this approach, the membrane is used to supply (and to distribute $\mathrm{H}_{2}$ homogeneously throughout the entire length of the membrane, i.e., through the catalyst bed) the extra $\mathrm{H}_{2}$ needed to achieve the stoichiometric $\mathrm{H}_{2} / \mathrm{CO}$ ratio into the FTS reaction chamber ensuring a proper distribution of the $\mathrm{H}_{2}$ through the entire catalyst bed. The pressure in the permeate chamber was set at $1.0 \mathrm{MPa}\left(46 / 46 / 8\right.$ of $\left.\mathrm{H}_{2} / \mathrm{CO} / \mathrm{N}_{2}\right)$. In order to create a driving force to allow $\mathrm{H}_{2}$ to permeate through the membrane into the reaction zone, an $\mathrm{H}_{2}$ partial pressure difference of $0.44 \mathrm{MPa}$ was set $\left(\Delta P_{\mathrm{H} 2}^{\mathrm{i}}=P_{\mathrm{H} 2}{ }^{\text {ret }}-P_{\mathrm{H} 2}{ }^{\text {perm }}=0.44 \mathrm{MPa}\right)$ by adjusting the pressure of the outer chamber to $1.2 \mathrm{MPa}\left(\mathrm{H}_{2} / \mathrm{He}=75 / 25\right)$. In order to obtain the desired $\mathrm{H}_{2} / \mathrm{CO}$ ratio of 2 in the catalyst bed during the FTS at the selected GHSV, the $\mathrm{H}_{2}$ flux permeated to the reaction zone was calculated previous to each FTS reaction. The permeated $\mathrm{H}_{2}$ flux was calculated by subtracting the $\mathrm{H}_{2}$ flow feed at the inlet of the membrane side from the non-permeated $\mathrm{H}_{2}$ flow measured at the retentate side at the outlet of the reactor. Thus, in the reaction zone, a syngas with an $\mathrm{H}_{2} / \mathrm{CO}$ ratio of 2 at $7500 \mathrm{~mL}_{\mathrm{H} 2+\mathrm{CO}} / \mathrm{g}_{\text {cat }} / \mathrm{h}$ is set.

Fig. 4a shows the evolution of the $\mathrm{CO}$ conversion with timeon-stream (TOS) obtained at $553 \mathrm{~K}$ using the $\mathrm{H}_{2}$-PBMR FTS concept using the Pd/Ag membrane. For reference, the results obtained with a conventional FTS-PBR measured under similar reaction conditions, i.e., $553 \mathrm{~K}, 1.0 \mathrm{MPa}, 7500 \mathrm{~mL}_{\text {syngas }} / \mathrm{h} / \mathrm{g}_{\text {cat }}$ and $\mathrm{H}_{2} / \mathrm{CO}$ ratios of 1 and 2 are also shown.

Noticeably, the $\mathrm{H}_{2}$-distributed PBMR concept using $\mathrm{H}_{2}$-poor syngas at the inner side of the membrane, $\left(\mathrm{H}_{2} / \mathrm{CO}=1\right)$ and supplying extra $\mathrm{H}_{2}$ from the outer side of the membrane, renders similar initial $\mathrm{CO}$ conversion values compared to those obtained with the traditional FTS PBR with $\mathrm{H}_{2} / \mathrm{CO}=2$ and significantly higher than those with a PBR using a $\mathrm{H}_{2}$-poor syngas $\left(\mathrm{H}_{2} / \mathrm{CO}=1\right)$. As shown in Fig. 4b, the initial selectivity towards the different products is significantly influenced by the presence of the membrane. Thus, the production of $\mathrm{C}_{1}$ decreased from $\mathrm{Ca} .22 \%$ in the traditional PBR $\left(\mathrm{H}_{2} / \mathrm{CO}=2\right)$ to $5.7 \%$ in the PBMR. The selectivity towards light hydrocarbons remains similar but the production of longchain hydrocarbons, $\mathrm{C}_{5-10}$ and $\mathrm{C}_{10+}$ fractions increases noticeably in the PBMR, especially the latter which increases from ca. $15.6 \%$ to $49.4 \%$. Fig. $4 \mathrm{~b}$ also shows the results of numerical simulation results of the comparison of the PBR with the PBMR concept. The numerical model describes qualitatively the same results, showing a decreased $\mathrm{CH}_{4}$ production and increased $\mathrm{C}_{5+}$ production when using the membrane reactor concept, although to a lesser extent. Discrepancies may come forth due to the fact that the simulation results were taken from steady-state operation, and the kinetic model for the catalyst requires further fine tuning (i.e., automated fitting based on larger data sets) in order to change qualitative agreement into quantitative agreement.

However, after a few hours on stream, the CO conversion recorded using the $\mathrm{H}_{2}$-PBMR drops to levels comparable to the ones recorded with the traditional PBR fed with a syngas with $\mathrm{H}_{2} / \mathrm{CO}=1$. Alongside with the decrease in the $\mathrm{CO}$ conversion, we observed a reduction of the $\mathrm{H}_{2}$ permeation rate through the membrane. Such an effect could be due to membrane deactivation by adsorbed $\mathrm{CO}$ species and/or blocking of membrane pores by adsorption of waxes formed during the FTS. Both these effects could explain the observed decrease in the $\mathrm{H}_{2}$ permeation rate through the membrane resulting in a $\mathrm{H}_{2}$-poor syngas within the FTS reaction chamber and consequently to a decrease in the CO conversion level.
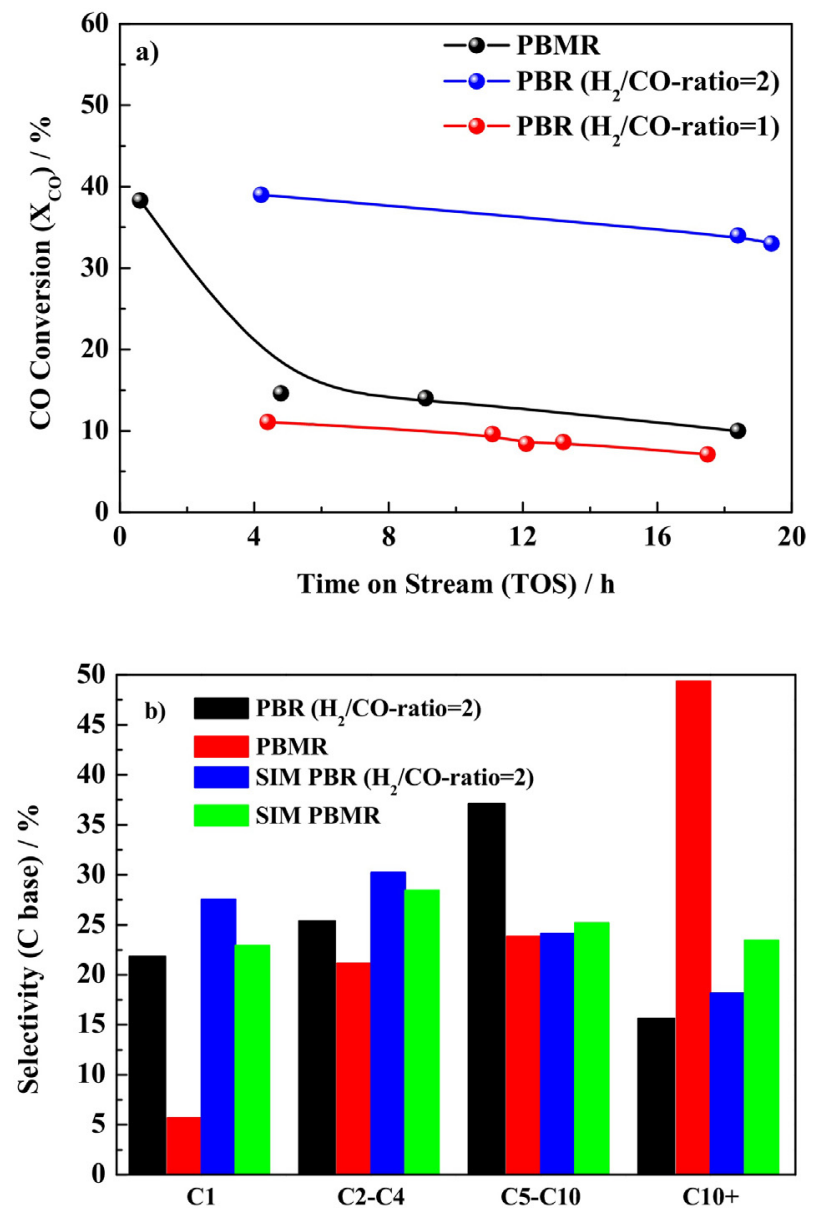

Fig. 4. (a) $\mathrm{CO}$ conversion at $523 \mathrm{~K}$ vs TOS in $\mathrm{H}_{2}-\mathrm{PBMR}\left(\mathrm{H}_{2} / \mathrm{CO}=1\right)$ perm (black) and in a conventional FTS PBR with $\mathrm{H}_{2} / \mathrm{CO}=2$ (blue) and $\mathrm{H}_{2} / \mathrm{CO}=1$ (red). $\mathrm{P}=1.0 \mathrm{MPa}$, GHSV= $7500 \mathrm{~mL}_{\mathrm{CO}+\mathrm{H} 2} / \mathrm{g}_{\text {cat }} / \mathrm{h}$ and $\Delta P_{\mathrm{H} 2}^{\mathrm{i}}=0.35 \mathrm{MPa}$. (b) Product selectivity for $\mathrm{PBR}_{2} / \mathrm{CO}=2$ (black) and PBMR (red) during the first hours of reaction, compared to model results (blue and green). (For interpretation of the references to color in this figure legend, the reader is referred to the web version of this article).

In addition, it may cause catalyst deactivation due to the formation of coke. Fig. 4a shows that after $\mathrm{ca}$. $10 \mathrm{~h}$ on stream the $\mathrm{H}_{2}$-PBMR behaves as a conventional PBR fed with $\mathrm{H}_{2}$-poor syngas $\left(\mathrm{H}_{2} / \mathrm{CO}=1\right)$. Similar CO conversion levels of around $10 \%$ and $15 \%$ are recorded for both configurations suggesting that $\mathrm{H}_{2}$-poor syngas is responsible for the decreasing $\mathrm{CO}$ conversion recorded using $\mathrm{H}_{2}-\mathrm{PBMR}$. The slightly higher $\mathrm{CO}$ conversion obtained with the $\mathrm{H}_{2}$-PBMR could indicate that a fraction of $\mathrm{H}_{2}$ is still permeating through the membrane, but not enough to maintain the FTS stoichiometric syngas ratio $\mathrm{H}_{2} / \mathrm{CO}$ of 2 .

Fig. 5 shows a picture of the inner side of the membrane tube recovered after the FTS reaction in the $\mathrm{H}_{2}$-PBMR. The image clearly shows the presence of waxes in the inner side of the tube (in the catalytic zone), which probably result in the blocking of tube's pores, thus impeding $\mathrm{H}_{2}$ permeation to the reaction chamber.

As shown above, Pd/Ag membranes are capable of supplying extra $\mathrm{H}_{2}$ to the FTS reaction zone, so that the $\mathrm{H}_{2} / \mathrm{CO}$ ratio can be adjusted to the desired stoichiometric FTS ratio. By doing that, $\mathrm{CO}$ conversions obtained in a $\mathrm{H}_{2}$-PBMR and in a traditional packed bed reactor are similar. This behavior, however, is not a significant advantage of the use of the PBMR over the traditional PBR for FTS. However, as also shown in Fig. 4b, conducting the FTS in a $\mathrm{H}_{2}-\mathrm{PBMR}$ results in a higher fraction of high molecular weight hydrocarbons and lower methane production than with a conventional PBR with $\mathrm{H}_{2} / \mathrm{CO}=2$. Fig. 4 b compares the products selectivity at the early 


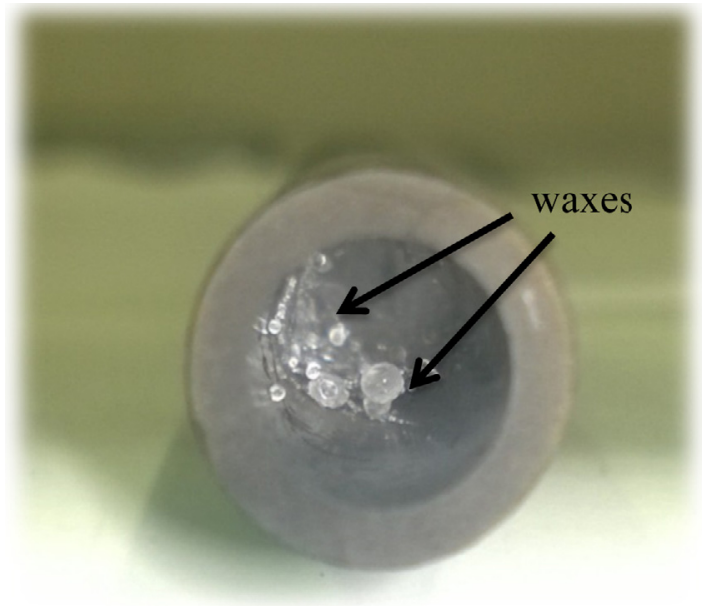

Fig. 5. Image of the $\mathrm{H}_{2}$-perm membrane recovered after the FTS synthesis. The presence of high molecular hydrocarbons (waxes) in the inner side of the membrane (the catalytic zone) is shown.

stages of the FTS (TOS $<5 \mathrm{~h}$ ), i.e., before membrane deactivation occurred. As observed, the production of high molecular weight hydrocarbons increased by a factor of 3 (ca. three times higher) and the production of methane is lower in the $\mathrm{H}_{2}$-PBMR than in the PBR. Both positive effects are probably related to an intrinsic property of the $\mathrm{Ag} / \mathrm{Pd}$ membranes, which is the homogeneous distribution of $\mathrm{H}_{2}$ along the entire length of the membrane. As a consequence, the $\mathrm{H}_{2} / \mathrm{CO}$ ratio within the whole catalytic bed length is better controlled and remains constant in the entire catalyst bed so that areas with local concentrations of $\mathrm{H}_{2}$ higher (which favor the production of methane) or lower (which favor the production of low molecular weight hydrocarbons) than the stoichiometric FTS value $\left(\mathrm{H}_{2} / \mathrm{CO}=2\right)$, prevailing in the conventional PBR, are circumvented.

With the aim to minimize the observed decrease in the $\mathrm{H}_{2}$ permeation rate through the $\mathrm{Pd} / \mathrm{Ag}$ membrane, FTS experiments were conducted at higher temperatures $(553 \mathrm{~K})$. Otherwise, the same reaction conditions were used. Feed flow rates were adjusted to reach the same GHSV $=7500 \mathrm{~mL}_{\mathrm{CO}+\mathrm{H} 2} / \mathrm{g}_{\text {cat }} / \mathrm{h}$. Syngas with a $\mathrm{H}_{2} / \mathrm{CO}=1$ ratio was directly fed into the reaction side of the $\mathrm{H}_{2}$ PBMR, while extra $\mathrm{H}_{2}$ to achieve an overall $\mathrm{H}_{2} / \mathrm{CO}=2$ was supplied via the membrane. In the PBR, syngas with $\mathrm{H}_{2} / \mathrm{CO}$ ratios of 1 and 2 was used. Fig. 6a displays the evolution of the $\mathrm{CO}$ conversion with time-on-stream (TOS) obtained at $553 \mathrm{~K}$ with the $\mathrm{H}_{2}$-PBMR and the conventional PBR reactor. Fig. $6 \mathrm{~b}$ shows the selectivity towards the different fractions of hydrocarbons at initial TOS $(T<5 \mathrm{~h})$.

As clearly observed in Fig. 6a, increasing the reaction temperature to $553 \mathrm{~K}$ results in higher CO conversions than at $523 \mathrm{~K}$ (see Fig. 4) in all configurations under study. The CO conversion recorded with the $\mathrm{H}_{2}$-PBMR is higher than that measured in the PBR with $\mathrm{H}_{2} / \mathrm{CO}=1$, but lower than that recorded with a PBR with $\mathrm{H}_{2} / \mathrm{CO}=2$. This trend is similar to the one reported for the FTS experiments recorded at $523 \mathrm{~K}$ (see above). However, conducting the FTS at $553 \mathrm{~K}$ prevents the strong deactivation observed at $523 \mathrm{~K}$, resulting in more stable CO conversion levels during time-on-stream in the $\mathrm{H}_{2}$-PBMR than at $523 \mathrm{~K}$ (see Fig. 4a). Two different yet complementary effects can justify the positive effect of the increasing reaction temperature. On the one hand, by increasing temperature the hydrogen permeance through the membrane increases. This feature results in a lower production of high molecular weight hydrocarbons and hence to a lower membrane deactivation. On the other hand, it is well known that the production of low molecular weight hydrocarbons increases with the increasing temperature. Combined, these effects lead to a lower production of high molecular weight hydrocarbons at $553 \mathrm{~K}$ than at $523 \mathrm{~K}$ as observed from
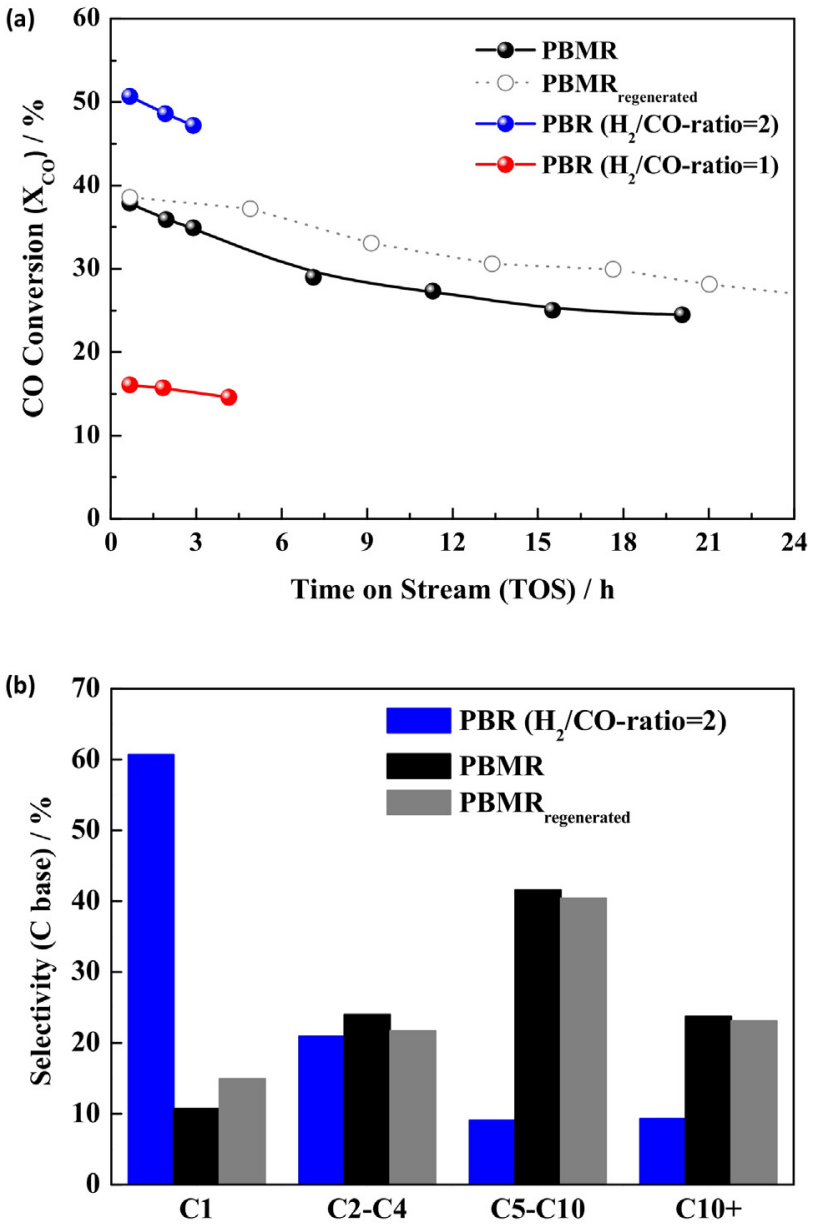

Fig. 6. (a) CO conversion at $553 \mathrm{~K}$ vs time on stream with catalyst RuB1Ti in PBMR $\left(\mathrm{H}_{2} / \mathrm{CO}=1\right)_{\text {perm }}$ (black color) and regenerated (open circles), PBR with $\mathrm{H}_{2} / \mathrm{CO}=2$ (blue color) and $\mathrm{H}_{2} / \mathrm{CO}=1$ (red color), $P=1 \mathrm{MPa}, \mathrm{GHSV}=7500 \mathrm{~mL}_{\mathrm{CO}+\mathrm{H} 2} / \mathrm{g}_{\text {cat }} / \mathrm{h}$ and $\Delta P_{\mathrm{H} 2}^{\mathrm{i}}=0.35 \mathrm{MPa}$. (b) Product selectivity for PBR $\mathrm{H}_{2} / \mathrm{CO}=2$ (blue bars), PBMR (black bars) and PBMR after thermal regeneration (green bars) during the first hours of reaction. (For interpretation of the references to color in this figure legend, the reader is referred to the web version of this article).

Fig. $4 \mathrm{~b}$ and Fig. $6 \mathrm{~b}$, and as a consequence of a lower membrane deactivation. This performance suggests that $\mathrm{H}_{2}$ permeation can be successfully maintained during the course of the experiment.

Although increasing the reaction temperature leads to higher CO conversions, the production of high molecular weight hydrocarbons decreases, while that of $\mathrm{CH}_{4}$, an undesired product of the CTL and GTL processes, increases. For instance, $\mathrm{CH}_{4}$ selectivity values of $\mathrm{ca}$. $22 \%$ and $61 \%$ are recorded with the PBR $\left(\mathrm{H}_{2} / \mathrm{CO}=2\right)$ at 523 and $553 \mathrm{~K}$, respectively. Although the impact of producing $\mathrm{CH}_{4}$ during the BTL process may not be as detrimental as in the CTL or GTL processes, the $\mathrm{CH}_{4}$ production at $553 \mathrm{~K}$ is still too high. However, and in line with the results obtained at $523 \mathrm{~K}$, the experiments conducted at $553 \mathrm{~K}$ with the $\mathrm{H}_{2}$-PBMR led to a significantly lower production of methane $\left(\mathrm{C}_{1}\right.$ selectivity $\left.\mathrm{ca} .11 \%\right)$ as compared to that obtained in the PBR configuration ( $C_{1}$ selectivity $c a .61 \%$ ) along with an increase of the selectivity towards high molecular weight hydrocarbons $\left(\mathrm{C}_{10}{ }^{+}\right)$of about 2.5 times; see Fig. $6 \mathrm{~b}$. This effect is remarkable and it compensates for the consequences of conducting the FTS at temperatures as high as $553 \mathrm{~K}$, opening new promising possibilities for the use of $\mathrm{H}_{2}$-PBMR for FTS.

Although to a lesser extent than when conducted at $523 \mathrm{~K}$, a certain decrease in the CO conversion with TOS was also observed at $553 \mathrm{~K}$. As shown above, this effect could be related to the formation of waxes in the inner side of the membrane that could 

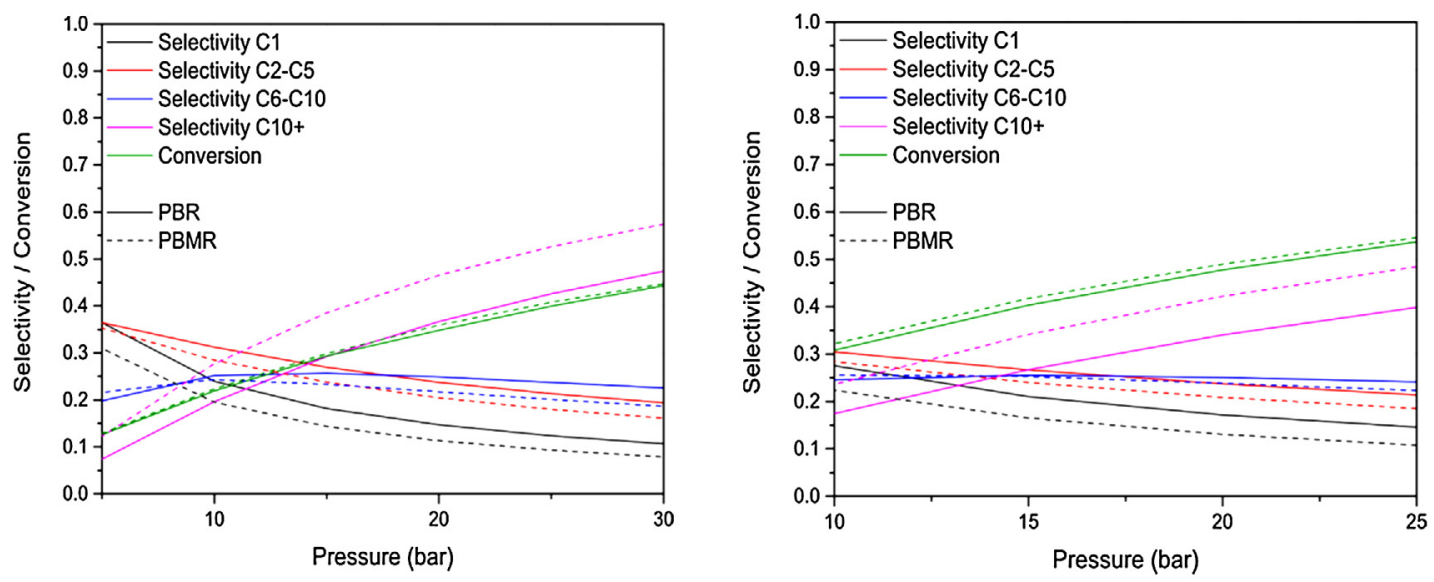

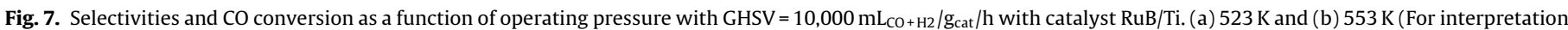
of the references to color in this figure legend, the reader is referred to the web version of this article).

\section{Table 5}

CO conversion and productivity using catalyst RuB1Ti in PBMR and PBR (syngas

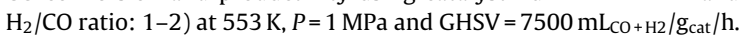

\begin{tabular}{llll}
\hline FTS concept & $X_{\mathrm{CO}}(\%)$ & $\mathrm{g}_{\mathrm{C} 5+} / \mathrm{g}_{\text {cat }} / \mathrm{h}$ & $\mathrm{g}_{\mathrm{CH} 4} / \mathrm{g}_{\text {cat }} / \mathrm{h}$ \\
\hline $\mathrm{H}_{2}-\mathrm{PBMR}$ & 37.9 & 0.39 & 0.056 \\
$\mathrm{PBR}_{2} / \mathrm{CO}=2$ & 50.7 & 0.23 & 0.450 \\
$\mathrm{PBR}_{2} / \mathrm{CO}=1$ & 14.1 & 0.17 & 0.086 \\
\hline
\end{tabular}

prevent $\mathrm{H}_{2}$ permeation to the reactor side. In order to regenerate the membrane, the reaction was stopped after $20 \mathrm{~h}$ on stream and the membrane was subjected to an in situ heat treatment at $573 \mathrm{~K}$ under a flow of $\mathrm{H}_{2}$ diluted in $\mathrm{He}(15 \%)$ in the outer side of membrane at and flowing pure He through the inner compartment of the membrane for $12 \mathrm{~h}$. The regeneration was successful and the system recovered the same (or even higher) FT activity level (CO conversions) obtained during the first FTS test (see Fig. 6a) and the same selectivity towards the different fraction of hydrocarbons (see Fig. 6b).

Table 5 summarizes the CO conversion and productivity towards selected product families obtained with the $\mathrm{H}_{2}$-distributed PBMR concept with the $\mathrm{Pd} / \mathrm{Ag}$ membranes using $\mathrm{H}_{2} / \mathrm{CO}=1$ at the inner part of the reactor compared to the ones obtained with a traditional FTS PBR with $\mathrm{H}_{2} / \mathrm{CO}=1$ or $\mathrm{H}_{2} / \mathrm{CO}=2$.

As observed in Table 5, the conversion of $\mathrm{CO}$ with the $\mathrm{H}_{2}$-PBMR is lower than that obtained in the fixed bed reactor with stoichiometric syngas $\left(\mathrm{H}_{2} / \mathrm{CO}=2\right)$. However, by distributing $\mathrm{H}_{2}$ through the membrane, a higher production of high molecular weight hydrocarbons $\left(\mathrm{C}_{5+}\right)$ and a significant decrease in $\mathrm{CH}_{4}$ production (of $\mathrm{ca}$. one order of magnitude) are observed. These results demonstrate for the first time experimentally that the use of membrane reactors with a distributed $\mathrm{H}_{2}$ feed via Pd/Ag membranes can increase the production of the desired fraction of high molecular weight hydrocarbons provided that suitable FTS reaction conditions are identified. In addition, the results obtained confirm the predictions of recent models developed to study the use of different configurations of membrane reactors for FTS which predict the formation of a higher yield to heavier hydrocarbons fraction [16-18].

\subsection{Numerical parameter study}

The numerical model was used to further study the effect of the pressure and temperature on the selectivity towards different fractions using the packed bed reactor and Packed Bed Membrane Reactor concepts. The trend of conversion and selectivities for different fractions as a function of the pressure is shown in Fig. 7. It is clear that for all cases, the membrane reactor concept is more selective towards long-chain components.

\section{Conclusions}

Despite the current mismatch between optimum temperature reaction conditions for the FTS and optimum temperature working conditions of the Pd/Ag membrane, this work has demonstrated experimentally the valuable use of the $\mathrm{H}_{2}$-distributed feeding concept for the FTS using a PBMR. The best conditions found for the $\mathrm{H}_{2}$-PBMR for FTS imply using a $\mathrm{H}_{2} / \mathrm{CO}$ feed $=1$ inside the reactor while supplying extra $\mathrm{H}_{2}$ (to reach an overall $\mathrm{H}_{2} / \mathrm{CO}=2$ ) via the membrane and a temperature of $553 \mathrm{~K}$. The $\mathrm{CO}$ conversion recorded with the $\mathrm{H}_{2}$-distributed feeding PBMR concept for FTS with $\left(\mathrm{H}_{2} / \mathrm{CO}=1\right)$ is lower than that obtained in a conventional PBR feed with $\mathrm{H}_{2} / \mathrm{CO}=2$ but the selectivity towards the targeted highmolecular hydrocarbons by $\mathrm{H}_{2}$-distribution in the PBMR increases by a factor of 3 .

In addition, the newly synthesized catalyst Ru-B/Ti was modeled according to conventional kinetic models based on a Co-based catalyst with updated kinetic rate parameters. The kinetic model was built into a numerical reactor model which confirms the experimental results of a decreased $\mathrm{CH}_{4}$ and increased $\mathrm{C}_{5+}$ selectivity.

\section{Acknowledgments}

The research under this project is receiving funding from the European Union Seventh Framework Programme (FP7/2007-2013) under grant agreement NMP3-LA.2011-262840 (DEMCAMER). Note: “The present publication reflects only the authors' views and the Union in not liable for any use that may be made of the information contained therein"

\section{References}

[1] M.E. Dry, The Fischer-Tropsch process: 1950-2000, Catal. Today 71 (2002) $227-241$.

[2] C.N. Hamelinck, A.P.C. Faaij, H. den Uil, H. Boerrigter, Production of FT transportation fuels from biomass; technical options, process analysis and optimisation, and development potential, Energy 29 (2004) 1743-1771.

[3] G.W. Huber, S. Iborra, A. Corma, Synthesis of transportation fuels from biomass: chemistry, catalysts, and engineering, Chem. Rev. 106 (2006) 4044-4098.

[4] E. van Steen, M. Claeys, Fischer-Tropsch catalysts for the biomass-to-liquid process, Chem. Eng. Tech. 31 (2008) 655-666.

[5] J.M. González-Carballo, F.J. Pérez-Alonso, M. Ojeda, F.J. García-García, J.L.G. Fierro, S. Rojas, Evidences of two-regimes in the measurement of Ru particle size effect for co dissociation during Fischer-Tropsch synthesis, ChemCatChem 6 (2014) 2084-2094. 
[6] J.M.G. Carballo, J. Yang, A. Holmen, S. García-Rodríguez, S. Rojas, M. Ojeda, J.L.G. Fierro, Catalytic effects of ruthenium particle size on the Fischer-Tropsch synthesis, J. Catal. 284 (2011) 102-108.

[7] J.M. González Carballo, E. Finocchio, S. García, S. Rojas, M. Ojeda, G. Busca, J.L.G. Fierro, Support effects on the structure and performance of ruthenium catalysts for the Fischer-Tropsch synthesis, Catal. Sci. Technol. 1 (2011) 1013-1023.

[8] J. Kang, S. Zhang, Q. Zhang, Y. Wang, Ruthenium nanoparticles supported on carbon nanotubes as efficient catalysts for selective conversion of synthesis gas to diesel fuel, Angew. Chem.-Int. Ed. 48 (2009) 2565-2568.

[9] C.X. Xiao, Z.P. Cai, T. Wang, Y. Kou, N. Yan, Aqueous-phase Fischer-Tropsch synthesis with a ruthenium nanocluster catalyst, Angew. Chem.-Int. Ed. 47 (2008) 746-749.

[10] G.P. Van Der Laan, A.A.C.M. Beenackers, Kinetics and selectivity of the Fischer-Tropsch synthesis: a literature review, Catal. Rev. Sci. Eng. 41 (1999) 255-318.

[11] M.P. Rohde, D. Unruh, G. Schaub, Membrane application in Fischer-Tropsch synthesis to enhance $\mathrm{CO}_{2}$ hydrogenation, Ind. Eng. Chem. Res. 44 (2005) 9653-9658.

[12] M.P. Rohde, D. Unruh, G. Schaub, Membrane application in Fischer-Tropsch synthesis reactors-overview of concepts, Catal. Today 106 (2005) 143-148.

[13] S. Léonard, S. Miachon, D. Vanhove, Récents Progres en Génie des Procédés 89 (2003) 226-234.

[14] D. Vanhove, S. Léonard, Récents Progres en Génie des Procédés 89 (2003) 194.

[15] L. Guillou, S. Léonard, V. Le Courtois, E. Payen, D. Vanhove, Proceedings of ICCMR-6, (2004).

[16] M.R. Rahimpour, H. Elekaei, A comparative study of combination of Fischer-Tropsch synthesis reactors with hydrogen-permselective membrane in GTL technology, Fuel Process. Technol. 90 (2009) 747-761.

[17] S.G.A. Ghareghashi, H. Hashemipour, Theoretical analysis of oxidative coupling of methane and Fischer Tropsch synthesis in two consecutive reactors: comparison of fixed bed and membrane reactor, J. Ind. Eng. Chem. 19 (2013) 1811-1826.

[18] H. Nouryzadeh, D. Iranshahi, Hydrogen and gasoline production through the coupling of Fischer-Tropsch synthesis and cyclohexane dehydrogenation in a thermally coupled membrane reactor, Pet. Coal 56 (2014) 231-248.

[19] F. Gallucci, E. Fernandez, P. Corengia, M. van Sint Annaland, Recent advances on membranes and membrane reactors for hydrogen production, Chem. Eng. Sci. 92 (2013) 40-66.

[20] E. Fernandez, A. Helmi, K. Coenen, J. Melendez, J.L. Viviente, D.A. Pacheco Tanaka, M. van Sint Annaland, F. Gallucci, Development of thin Pd-Ag supported membranes for fluidized bed membrane reactors including WGS related gases, Int. J. Hydrog. Energy 40 (2015) 3506-3519.

[21] P.C. Munasinghe, S.K. Khanal, Biomass-derived syngas fermentation into biofuels, in: Biofuels, Elsevier Inc., Amstredam, 2011, pp. 79-98.

[22] I. Agote, M.A. Lagos, E. Fernandez, A. Arratibel, D.A.P. Tanaka, J.A. Calero, Metallic porous supports and ceramic interface layer development for $\mathrm{H}_{2}$ separation membranes, Powder Metall. 57 (2014) 232-235.

[23] C.G. Visconti, E. Tronconi, L. Lietti, R. Zennaro, P. Forzatti, Development of a complete kinetic model for the Fischer-Tropsch synthesis over $\mathrm{Co} / \mathrm{Al}_{2} \mathrm{O}_{3}$ catalysts, Chem. Eng. Sci. 62 (2007) 5338-5343.

[24] C.G. Visconti, E. Tronconi, L. Lietti, P. Forzatti, S. Rossini, R. Zennaro, Detailed kinetics of the Fischer-Tropsch synthesis on cobalt catalysts based on H-assisted CO activation, Top. Catal. 54 (2011) 786-800.

[25] C.G. Visconti, M. Mascellaro, Calculating the product yields and the vapor-liquid equilibrium in the low-temperature Fischer-Tropsch synthesis, Catal. Today 214 (2013) 61-73.

[26] R. Sanz, J.A. Calles, D. Alique, L. Furones, New synthesis method of Pd membranes over tubular PSS supports via "pore-plating" for hydrogen separation processes, Int. J. Hydrog. Energy 37 (2012) 18476-18485. 